\title{
Activation of natural killer $T$ cells in NZB/W mice induces Th1-type immune responses exacerbating lupus
}

\author{
Defu Zeng, ${ }^{1}$ Yinping Liu, ${ }^{1}$ Stephane Sidobre, ${ }^{2}$ Mitchell Kronenberg, ${ }^{2}$ and Samuel Strober ${ }^{1}$ \\ ${ }^{1}$ Division of Immunology \& Rheumatology, Department of Medicine, Stanford University School of Medicine, Stanford, \\ California, USA \\ ${ }^{2}$ La Jolla Institute for Allergy and Immunology, San Diego, California, USA
}

\begin{abstract}
In vivo treatment of mice with the natural killer T (NKT) cell ligand, $\alpha$-galactosylceramide ( $\alpha$ GalCer), ameliorates autoimmune diabetes and experimental autoimmune encephalomyelitis (EAE) by shifting pathogenic Th1-type immune responses to nonpathogenic Th2-type responses. In the current study, in vivo activation of NKT cells in adult NZB/W mice by multiple injections of $\alpha$ GalCer induced an abnormal Th1-type immune response as compared with the Th2-type response observed in nonautoimmune C57BL/6 mice. This resulted in decreased serum levels of IgE, increased levels of IgG2a and IgG2a anti-double-stranded DNA (anti-dsDNA) Ab's, and exacerbated lupus. Conversely, treatment of NZB/W mice with blocking anti-CD1d mAb augmented Th2-type responses, increased serum levels of IgE, decreased levels of IgG2a and IgG2a anti-dsDNA Ab's, and ameliorated lupus. While total $\mathrm{CD} 4^{+} \mathrm{T}$ cells markedly augmented in vitro IgM anti-dsDNA Ab secretion by splenic $\mathrm{B}$ cells, the non-CD1d-reactive (CD1d- $\alpha$ GalCer tetramer-negative) $\mathrm{CD}^{+} \mathrm{T}$ cells (accounting for $95 \%$ of all $\mathrm{CD} 4^{+}$ $\mathrm{T}$ cells) failed to augment $\mathrm{Ab}$ secretion. The $\mathrm{CD} 1 \mathrm{~d}$-reactive tetramer-positive $\mathrm{CD} 4^{+} \mathrm{T}$ cells augmented anti-dsDNA Ab secretion about tenfold. In conclusion, activation of NKT cells augments Th1-type immune responses and autoantibody secretion that contribute to lupus development in adult $\mathrm{NZB} / \mathrm{W}$ mice, and anti-CD1d mAb might be useful for treating lupus.
\end{abstract}

J. Clin. Invest. 112:1211-1222 (2003). doi:10.1172/JCI200317165.

\begin{abstract}
Introduction
Systemic lupus erythematosus is an autoimmune disease characterized by antinuclear autoantibodies and multiorgan tissue injury, including immune complex glomerulonephritis (1-4). There are several murine models of lupus, including some induced by the injection of cells or antigens into nonautoimmune mice $(5-8)$. Others are hereditary, and the mice develop lupus spontaneously as they age (9-13). Hereditary lupus in female NZB/W $F_{1}$ hybrid mice is characterized by lethal immune complex glomerulonephritis, and IgG2a anti-double-stranded DNA (anti-dsDNA) Ab's have been reported to play a pathogenic role in glomerular injury $(4,14)$. Lupus in NZB/W mice closely resembles lupus in humans with severe glomerulonephritis $(1,15)$.

CD4 $\mathrm{T}$ cells play an important role in augmenting autoantibody secretion by autoreactive B cells in NZB/W mice, since anti-CD4 $\mathrm{mAb}$ therapy markedly ameliorates lupus in these mice and reduces serum levels of IgG anti-
\end{abstract}

Received for publication October 16, 2002, and accepted in revised form August 12, 2003.

Address correspondence to: Defu Zeng, Gonda Building, Room 2017, Department of Diabetes and Endocrinology, The Beckman Research Institute, City of Hope National Medical Center, 1500 East Duarte Road, Duarte, California 91010-3000, USA. Phone: (626) 359-8111, ext. 62587; Fax: (626) 301-8136; E-mail: dzeng@coh.org.

Conflict of interest: The authors have declared that no conflict of interest exists.

Nonstandard abbreviations used: double-stranded DNA (dsDNA); natural killer T cells (NKT cells); $\alpha$-galactosylceramide $(\alpha \mathrm{GalCer})$; experimental autoimmune encephalomyelitis (EAE).
dsDNA Ab's (16). Autoreactive CD4 T cells in murine lupus have been shown to recognize nucleosomes and also peptides derived from anti-DNA Ab's (17-20). Recently, we have reported that CD1d-reactive transgenic $\mathrm{CD} 4 \mathrm{~T}$ cells induced lupus in $\mathrm{BALB} / \mathrm{c} \mathrm{nu} / n u$ recipients (8). CD1d-reactive CD4 $\mathrm{T}$ cells have also been reported to contribute to the pathogenesis of lupus in NZB/W mice (20). Studies of the role of T cell-derived cytokines in NZB/W lupus indicate that the Th1 cytokine IFN- $\gamma$ plays an important role in the development of disease as judged by the marked reduction of disease activity by anti-IFN- $\gamma$ therapy and worsening of the disease by administration of IFN- $\gamma(21,22)$. IFN- $\gamma$ is thought to facilitate the switch from IgM to IgG2a pathogenic autoantibodiess in NZB/W mice at about 6 months of age $(9,23)$, since this cytokine promotes isotype switching of activated B cells to IgG2a, whereas IL-4 promotes isotype switching to $\operatorname{IgG} 1$ and $\operatorname{IgE}(24,25)$.

Natural killer T cells (NKT cells) are an important early source of serum IFN- $\gamma$ and IL-4 after polyclonal activation of $\mathrm{T}$ cells in vivo with anti-CD3 mAb (26). It is possible that activation of the NKT cells during the development of lupus contribute to IFN- $\gamma$ production and disease activity. Mouse NKT cells express invariant V $\alpha 14 \mathrm{~J} \alpha 281$ TCRs that recognize phospholipid and glycolipid antigens bound to CD1d, a nonpolymorphic, non-MHC-encoded, MHC I-like antigen-presenting molecule expressed on APCs (27-31). $\alpha$-Galactosylceramide ( $\alpha \mathrm{GalCer}$ ) is a glycolipid that can bind to the invariant TCR and activate NKT cells in vitro and in vivo (29). In nonautoimmune BALB/c 
and C57BL/ 6 mice, however, activation of the NKT cells in vivo by $\alpha$ GalCer often resulted in a Th2-type immune response in which IL-4 activity predominated over that of IFN- $\gamma$. This, in turn, resulted in a polarization of conventional CD4 T cells toward Th2-type cytokines, increased serum IgE levels, and decreased serum IgG2a levels $(32,33)$.

Administration of $\alpha \mathrm{GalCer}$ in vivo has been reported to ameliorate spontaneous autoimmune diabetes in NOD mice and experimental autoimmune encephalomyelitis (EAE) induced by myelin basic protein in C57BL/6 mice (34-38). In both cases, autoimmune tissue injury is thought to be mediated by a proinflammatory Th1-type immune response, and $\alpha$ GalCer treatment shifts the immune response toward an antiinflammatory Th2 type $(34,35,37)$.

In the current study, we treated lupus in adult NZB/W mice with $\alpha \mathrm{GalCer}$. In contrast to the results of treating diabetes in NOD mice and $\mathrm{EAE}$ in $\mathrm{C} 57 \mathrm{BL} / 6$, in vivo treatment of female adult NZB/W mice with $\alpha$ GalCer augmented Th1-type immune responses and worsened lupus as judged by an earlier onset of proteinuria and mortality. We also treated adult NZB/W mice with a 6 -month course of an anti-CD $1 \mathrm{~d} \mathrm{mAb}$ that can block the in vitro interaction between CD1d molecules expressed on B cells and CD1d-reactive $T$ cells (8). The mAb therapy augmented Th2-type immune responses and ameliorated lupus. In addition, sorted CD1d-reactive $\mathrm{CD}^{+}{ }^{+} \mathrm{T}$ cells staining positively with a CD1d- $\alpha$ GalCer tetramer markedly augmented the secretion of IgM anti-dsDNA autoantibodies by splenic B cells, but the tetramer-negative CD4 T cells did not. These results link the abnormal Th1-type response observed after in vivo activation of $\mathrm{NZB} / \mathrm{W} \mathrm{NKT}$ cells to lupus disease activity. In addition, the latter cells have been identified as facilitators of autoantibody secretion by B cells early in disease development and potential targets for the treatment of lupus. Anti-CD1d mAb might be useful for treating lupus in adults.

\section{Methods}

Mice. C57BL/ 6 female mice were obtained from the Department of Comparative Medicine, Stanford University breeding facility. NZB/W female mice were purchased from The Jackson Laboratory (Bar Harbor, Maine, USA). C57BL/6 J $\alpha 281^{-/-}$mice were obtained from the laboratory of $\mathrm{M}$. Taniguchi (Chiba University, Chiba, Japan) (39) and were maintained at Stanford University animal facility.

Flow-cytometric analysis and sorting. Single cell suspensions of thymus, spleen, liver, and bone marrow cells were prepared and stained with mAb's as described previously $(20,39,40)$. Analysis and sorting were performed with a FACSVantage (Becton Dickinson Immunocytometry Systems, Mountain View, California, USA), and data were analyzed using FlowJo software (Tree Star, San Carlos, California, USA) $(20,41)$. The purity of sorted cells was greater than $98 \%$. The FITC-, phycoerythrin-, APC-, or Texas red-conjugated mAb's to mouse B220, CD19, IgM, IgD, CD1d, TCR $\alpha \beta$,
CD4, CD8, NK1.1, CD69, and CD44 were purchased from PharMingen (San Diego, California, USA). Preparation of and staining with CD1d- $\alpha$ GalCer tetramer was reported previously (42).

In vitro secretion of IgM and IgG. Sorted splenic $\mathrm{T}$ and $\mathrm{B}$ cell subsets were incubated in 96-well round-bottom plastic plates in complete RPMI medium with $10 \%$ FBS for $1-5$ days at $37^{\circ} \mathrm{C}$ in $5 \% \mathrm{CO}_{2}$. At the end of the culture period, supernatants were harvested, and the concentrations of IgM and IgG were measured with ELISA, using affinity-purified goat anti-mouse heavy chain-specific Ab's as described below.

ELISA assays. A standard sandwich ELISA was used to measure $\mathrm{Ab}$ isotype concentrations as described previously $(8,20)$. The concentration of $\operatorname{IgE}$ is expressed in units per milliliter, using a reference-positive standard of pooled serum from 6- to 7-month-old NZB/W mice. A 1:10 dilution of the standard serum was arbitrarily assigned a value of $100 \mathrm{U} / \mathrm{ml}$. Anti-dsDNA titers are expressed in units per milliliter, using a reference-positive standard of pooled serum from 6- to 7-month-old $\mathrm{NZB} / \mathrm{W}$ mice. A 1:100 dilution of this standard serum was arbitrarily assigned a value of $100 \mathrm{U} / \mathrm{ml}$.

In vitro stimulation of sorted tetramer-positive $C D 4^{+} T$ cells. Sorted tetramer-positive $\mathrm{CD}^{+}{ }^{+} \mathrm{T}$ cells from the spleens of $\mathrm{NZB} / \mathrm{W}$ or $\mathrm{C} 57 \mathrm{BL} / 6$ mice were placed in plastic plates $\left(5 \times 10^{3}\right.$ cells/well $)$ and stimulated with PMA and ionomycin for 48 hours as described previously (41). Supernatants were harvested at the end of the culture period, and the concentrations of IL-4 and IFN- $\gamma$ were measured by ELISA.

In vivo treatment of $N Z B / W$ mice with $\alpha$ GalCer and anti$C D 1 d m A b$. Mice were injected with $\alpha$ GalCer (Kirin Pharmaceutical Research Institute, Gunma, Japan) or PBS/vehicle at a dose of $4 \mu \mathrm{g} /$ mouse per injection as described previously $(33,34)$. Mice were injected with anti-CD1d mAb (rat IgG2b) from the hybridoma 1B1 (43) and the rat IgG2b isotype control (rat antihuman HLA Bw6) from hybridoma HB-152 (American Type Culture Collection, Manassas, Virginia, USA) as described previously (20).

Proteinuria of NZB/W mice was measured on a scale of 1-4+ using a colorimetric assay for albumin (Albustix; Miles Inc., Elkhart, Indiana, USA). Mice were considered to have proteinuria if at least two consecutive urine samples were greater than $2+$, according to the scale $(100 \mathrm{mg} / \mathrm{dl})(8,20)$. Serum levels of IgM, IgG, and $\operatorname{IgE}$, and IgG anti-dsDNA Ab's were measured with the ELISA, as described above.

Statistical analysis. Differences in proteinuria onset and survival time of groups were analyzed using log-rank test. Differences in percentage of T cell subsets, cytokine, and IgG concentrations in serum and culture supernatants were analyzed with a two-tailed Student's $t$ test.

\section{Results}

In vivo $\alpha$ GalCer treatment induces a Th1-type immune response in adult $N Z B / W$ mice. $\mathrm{C} 57 \mathrm{BL} / 6$ and $\mathrm{BALB} / \mathrm{c}$ mice given single injections of the invariant NKT cell 
TCR ligand, $\alpha$ GalCer, have been reported to develop a Th2-type shift of serum Ig isotypes with high levels of serum $\operatorname{IgE}$ (33). Secretion of $\operatorname{IgE}$ is augmented by IL-4 from Th2 cells. Immunizing those mice simultaneously with protein antigen and $\alpha \mathrm{GalCer}$ directs the $\mathrm{T}$ cell response to the antigen to a Th2 pattern (33), although this has not been found in every experiment (44). In the current study, we explored the impact of the administration of $\alpha$ GalCer in lupus-prone $\mathrm{NZB} / \mathrm{W}$ mice. We first compared the serum levels of IL-4 and IFN- $\gamma$ at 2, 6, and 18 hours after a single injection of $\alpha$ GalCer or PBS/vehicle in 8- to 12-weekold C57BL/6 and NZB/W mice. As shown in Figure 1, serum levels of IL- 4 in both strains of mice given $\alpha$ GalCer increased and peaked at 2 hours after injection, and the IL- 4 levels of NZB/W mice were twofold lower than C57BL/6 mice $(P<0.001)$. The serum levels of IFN- $\gamma$ peaked at 18 hours after injection, and the IFN- $\gamma$ levels of NZB/W mice were threefold higher than C57BL/6 mice $(P<0.001)$. Control NZB/W and C57BL/ 6 mice injected with the PBS/vehicle did not have detectable amounts of serum IL-4 or IFN- $\gamma$. C57BL $/ 6 \mathrm{Ja} 281^{-/-}$mice that are deficient in NKT cells did not have elevated serum levels of IL- 4 or IFN- $\gamma$ after $\alpha$ GalCer injection (Figure 1).

The difference in serum cytokine patterns in adult $\mathrm{NZB} / \mathrm{W}$ and C57BL/ 6 mice after $\alpha \mathrm{GalCer}$ injection was reflected by changes in serum levels of $\operatorname{IgE}$, an isotype upregulated by IL-4, and IgG2a, an isotype upregulated by IFN- $\gamma$ (45). As shown in Figure 2, a and b, 9 days after $\alpha$ GalCer injection, C57BL/ 6 mice had a threefold increase in $\operatorname{IgE}(P<0.001)$ and no significant change $(P>0.1)$ in serum IgG2a as compared with $\mathrm{C} 57 \mathrm{BL} / 6$ mice given PBS/vehicle control. By contrast, NZB/W mice had no significant changes in IgE levels, but there was a twofold increase in IgG2a as compared with $\mathrm{NZB} / \mathrm{W}$ mice given PBS/vehicle control.

A similar study was performed in 4-week-old instead of 8- to 12 -week-old NZB/W and C57BL/6 mice to determine whether the $\alpha \mathrm{GalCer}$-induced Th1-type shift in NZB/W mice precedes the development of IgM anti-dsDNA Ab's in the serum usually starting at an age of 8-12 weeks (46). As shown in Figure 1, $c$ and d, after a single injection of $\alpha$ GalCer, serum IL-4 levels peaked at 2 hours in both strains of young mice, and mean peak IL-4 levels in NZB/W mice were significantly lower than that in $\mathrm{C} 57 \mathrm{BL} / 6$ mice $(P<0.01)$. The peak IL-4 levels in young NZB/W and C57BL/6 mice were about twofold lower than in adult mice (Figure 1; $P<0.01)$. IL-4 was not detected in control mice given vehicle/PBS. Serum IFN- $\gamma$ levels peaked at $6-18$ hours after injection in both strains of young mice, and the mean peak IFN- $\gamma$ level in NZB/W mice was not significantly different from that in C57BL/6 mice (Figure 1d). The mean peak IFN- $\gamma$ levels in young NZB/W and C57BL/6 mice was about 20 -fold lower than in older mice after $\alpha$ GalCer injection $(P<0.001)$, however, and only slightly above background (Figure 1). Serum levels of $\operatorname{IgE}$ and $\operatorname{IgG} 2 \mathrm{a}$ were measured before and 9 days after injection. The serum IgE levels were not detectable before or after $\alpha$ GalCer injection in either strain of young mice (data not shown). The serum IgG2a levels were less than $0.2 \mu \mathrm{g} / \mathrm{ml}$ in both strains of mice before $\alpha$ GalCer injection, which is about 1,000-fold lower than in older mice (Figure 2), and $\alpha$ GalCer treatment did not induce a significant change (data not shown). These results indicate that the Th2-type immune responses in $\mathrm{C} 57 \mathrm{BL} / 6$ and the Th1-type immune

\section{Figure 1}

Kinetics of serum levels of IL-4 and IFN- $\gamma$ after single injection of $\alpha$ GalCer. C57BL/6, NZB/W, and J $\alpha 281^{-/-} \mathrm{C} 57 \mathrm{BL} / 6$ mice at age 8-12 weeks or 4 weeks were given a single injection of $\alpha G a l C e r$ or PBS/vehicle control, and serum levels of IL-4 and IFN- $\gamma$ were measured at 2 , 6 , and 18 hours after injection. (a and b) Data from 8- to 12week-old mice. (c and d) Data from 4-week-old mice. Bars show means of ten mice, and brackets show standard errors.
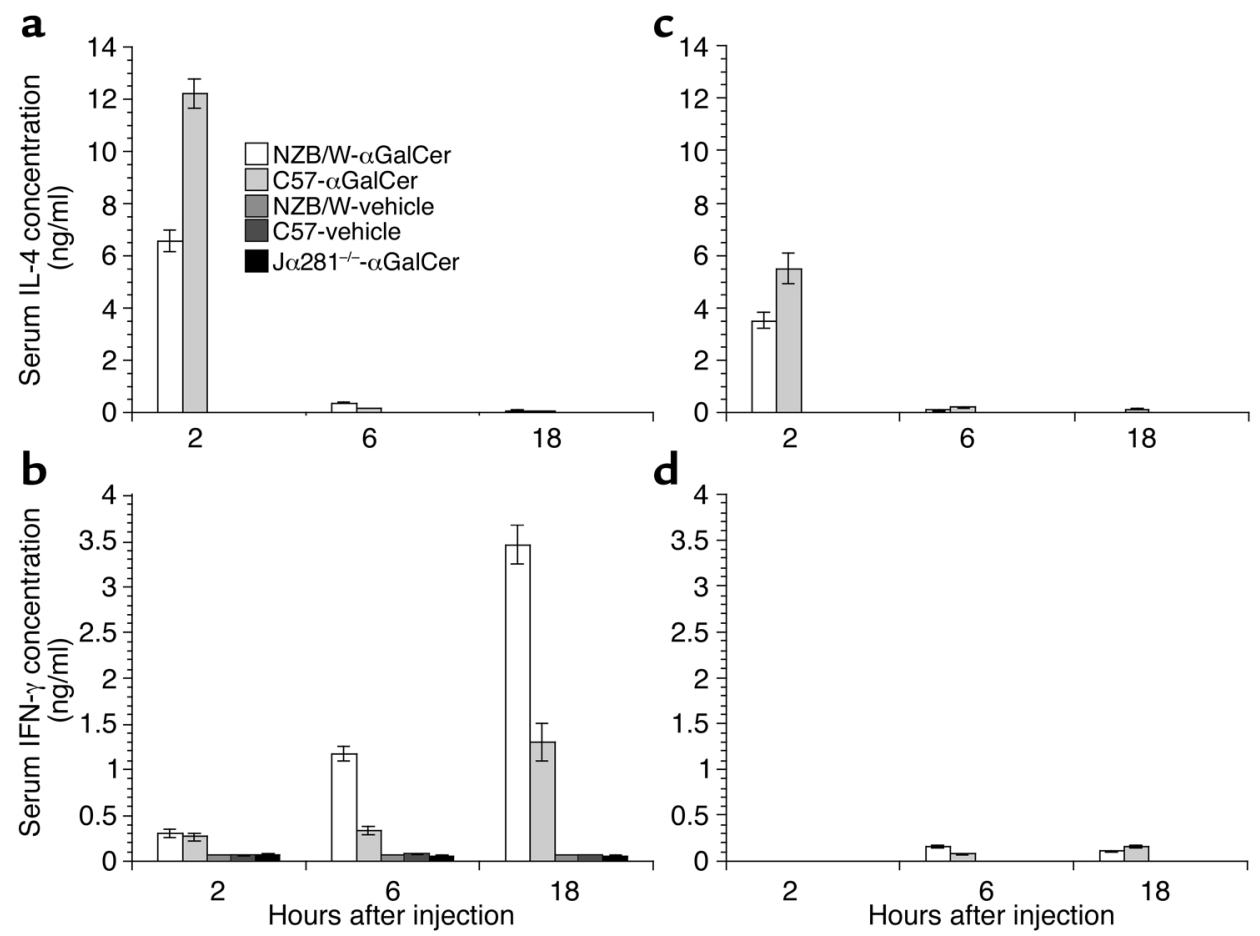

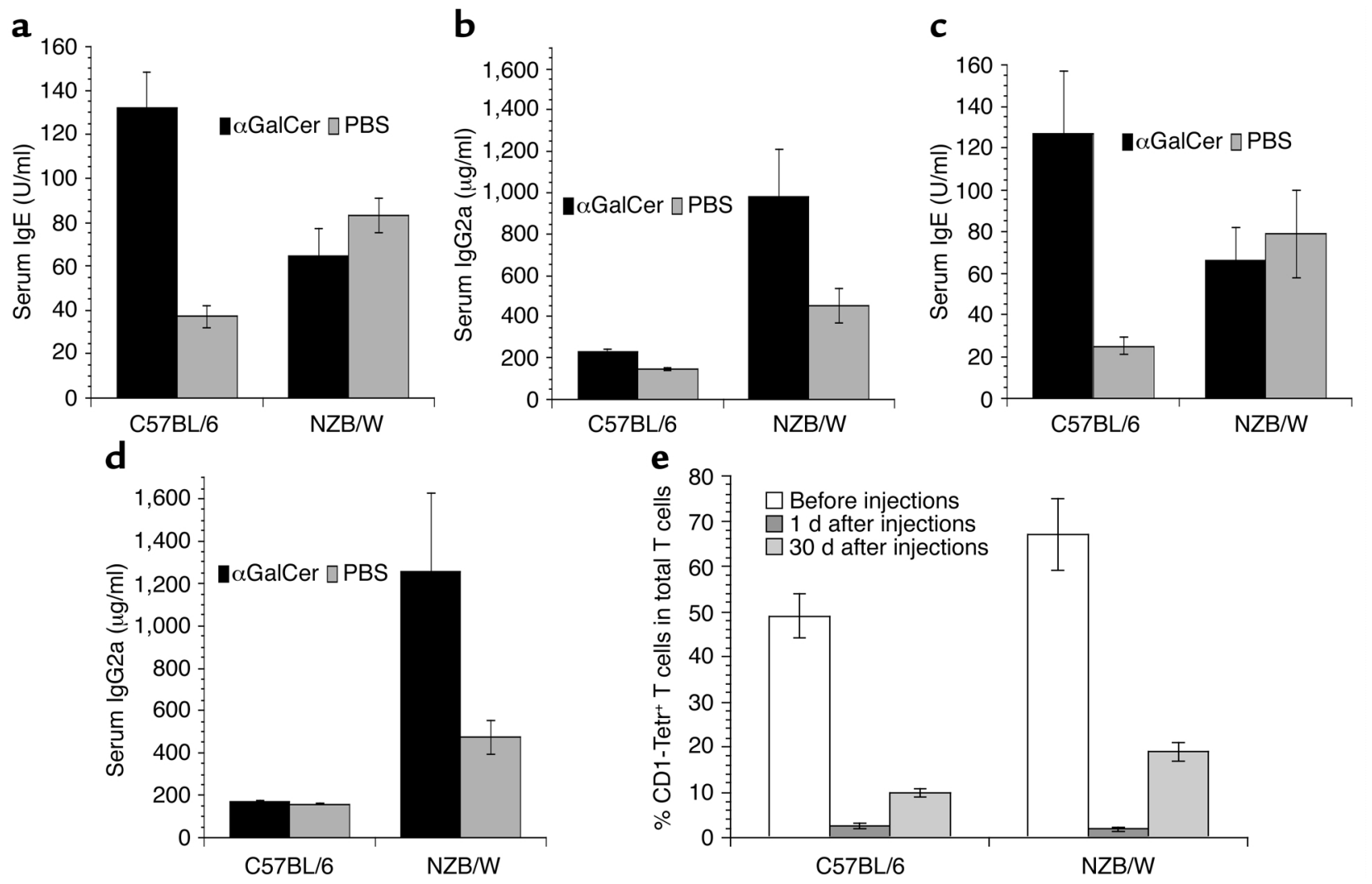

\section{Figure 2}

Treatment with $\alpha$ GalCer induced Th1- or Th2-type Ig isotype pattern in adult NZB/W or C57BL/ 6 mice. C57BL/6 and NZB/W mice (8-12 weeks old) were given single or multiple injections of $\alpha$ GalCer or PBS/vehicle control. (a and $\mathbf{b}$ ) Serum levels of IgE and IgG2a in C57BL/ 6 and NZB/W mice 9 days after having been given a single injection of $\alpha$ GalCer or PBS control. Bars show means of ten mice, and brackets show standard errors. (c and $\mathbf{d}$ ) Serum levels of IgE and IgG2a in C57BL/ 6 and NZB/W mice 30 days after completion of injections of $\alpha G$ alCer or PBS control twice a week for 2 weeks. Bars show means of ten mice, and brackets show standard errors. (e) Changes of the percentage of CD1d- $\alpha$ GalCer tetramer-positive T cells in livers of C57BL/ 6 and NZB/W mice before injection and 1 day and 30 days after last injection (twice a week for 2 weeks). Tetr ${ }^{+}$, tetramer positive. There are five mice at each time point. Bars show mean percentage of five mice, and brackets show standard errors.

responses in NZB/W mice after $\alpha$ GalCer treatment are detectable only in the older mice. The Th1-type shift in $\mathrm{NZB} / \mathrm{W}$ mice develops at about the same age as the development of serum IgM anti-dsDNA Ab's.

In additional experiments, 8 - to 12 -week-old NZB/W and $\mathrm{C} 57 \mathrm{BL} / 6$ mice were injected with $\alpha$ GalCer twice a week for 2 weeks. Four weeks after the last injection, the serum levels of IgE and IgG2a were measured. The results were similar to that after a single $\alpha \mathrm{GalCer}$ injection. Whereas IgE was markedly increased in C57BL/6 mice, IgG2a was markedly increased in NZB/W mice (Figure 2, $c$ and d). These results indicate that single as well as multiple injections of $\alpha \mathrm{GalCer}$ induces a Th2type serum Ig shift in adult C57BL/6 mice and a Th1type shift in adult NZB/W mice. The serum levels of IgE and IgG2a in adult NZB/W mice given PBS/vehicle control were twofold higher than in C57BL/6 mice given PBS/vehicle control (Figure $2, P<0.01$ ). This is an expected result of spontaneous polyclonal $\mathrm{B}$ cell activation in NZB/W mice $(46,47)$.

In further experiments, 4-week-old NZB/W and C57BL/ 6 mice were also injected with $\alpha \mathrm{GalCer}$ or
PBS/vehicle control twice a week for 2 weeks, and a kinetic measurement of serum levels of IgE, IgG2a, and IgG2a anti-dsDNA Ab's was carried out monthly for 5 months, starting at the age of 8 weeks ( 2 weeks after completion of $\alpha \mathrm{GalCer}$ injection). As shown in Figure 3, treatment of young NZB/W mice did not significantly $(P>0.1)$ change the serum levels of $\operatorname{IgE}, \operatorname{IgG} 2 \mathrm{a}$, and IgG2a anti-dsDNA $\mathrm{Ab}$ 's as compared with PBS/vehicle control at different time points over the 5 month period. In both groups, the IgG2a anti-dsDNA Ab's, which are the hallmark of lupus disease activity and development (1-4), increased progressively, indicating that the kinetics of disease development were neither accelerated nor slowed by the injection of $\alpha \mathrm{GalCer}$ in these young mice. The kinetics of the onset of proteinuria during an 8-month observation period was not significantly different $(P>0.1)$ in both groups (data not shown). At 9 months of age, five out of ten mice in each group had developed severe (a score greater than $3^{+}$) proteinuria, indicating a similar tempo of development of lupus glomerulonephritis in the two groups.

The $\alpha$ GalCer treatment of young C57BL/ 6 mice did not significantly change the serum levels of $\operatorname{IgE}$ or 
a

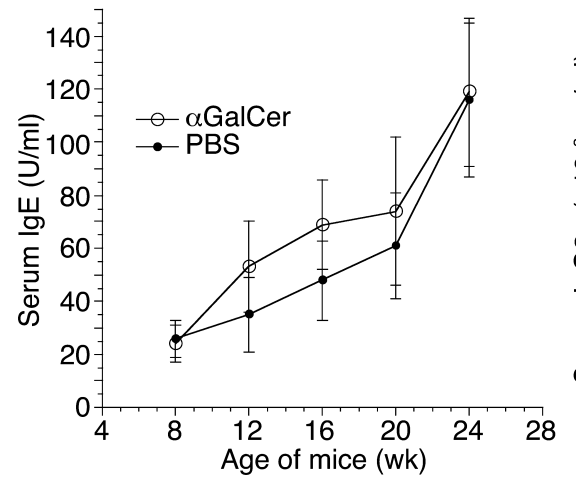

b

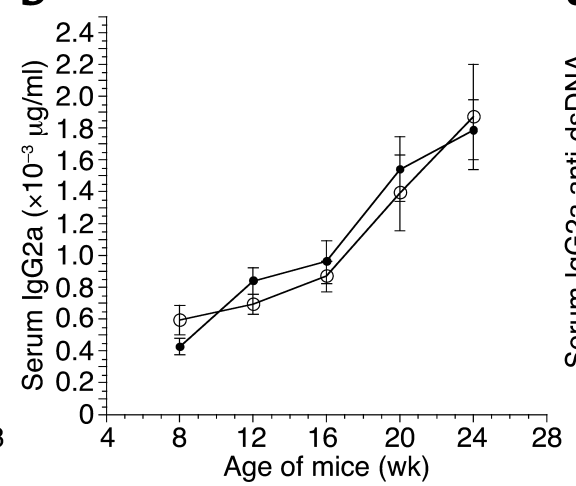

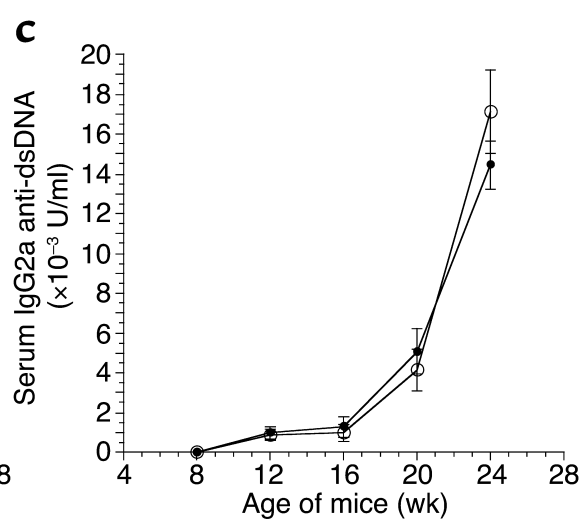

Figure 3

Treatment with $\alpha \mathrm{GalCer}$ did not induce Th1 - or Th2-type Ig isotype pattern in young NZB/W mice. Four-week-old NZB/W mice were injected with $\alpha G$ alCer or control PBS/vehicle twice a week for 2 weeks. Serial measurements of serum IgE, IgG2a, and IgG2a anti-dsDNA Ab's were shown $(\mathbf{a}-\mathbf{c})$, starting from the age of 8 weeks ( 2 weeks after completion of injection). There were ten mice in each group.

IgG2a as compared with the control mice given PBS/vehicle (data not shown). The IgG2a levels in these mice remained in the $200-300 \mu \mathrm{g} / \mathrm{ml}$ range during the entire observation period and were about tenfold lower than that of the NZB/W mice at 24 weeks of age. The IgG2a anti-dsDNA Ab's were undetectable at all the points in the C57BL/ 6 mice. These results indicate that single as well as multiple injections of $\alpha \mathrm{Gal}$ Cer did not augment either Th1-type or Th2-type immune responses in young NZB/W or young C57BL/6 mice, although the same treatment augmented Th1-type immune responses in adult NZB/W mice and Th2-type immune response in adult C57BL/ 6 mice. Taken together, the impact of $\alpha$ GalCer treatment on immune response was age dependent. In vivo $\alpha$ GalCer treatment results in the depletion of the CD1d- $\alpha$ GalCer tetramer-positive (henceforth called tetramer positive) NKT cells in the spleen and liver of C57BL/ 6 and BALB/c mice (42). Thus, the different changes induced by $\alpha$ GalCer treatment of adult 8- to 12 -week-old C57BL/6 and NZB/W mice might be explained by different patterns of NKT cell depletion rather than the results of NKT cell activation. Accordingly, we observed the changes of CD1d-reactive tetramer-positive $\mathrm{T}$ cells in the spleen and liver of C57BL/ 6 and NZB/W mice before and after multiple $\alpha \mathrm{GalCer}$ injections. As shown in Figure 2e, before injection about $50 \%$ of $\mathrm{T}$ cells in $\mathrm{C} 57 \mathrm{BL} / 6$ liver were tetramer positive and about $65 \%$ of $\mathrm{T}$ cells in NZB/W liver were tetramer positive. One day after the last injection, less than $3 \%$ of $\mathrm{T}$ cells in the liver of both strains were tetramer positive, and 30 days after the last injection there was a partial recovery of tetramer-positive $\mathrm{T}$ cells in the liver. At the latter point, $12 \%$ of the $\mathrm{T}$ cells in C57BL/ 6 liver and $20 \%$ of the T cells in NZB/W liver were tetramer positive. The change in the absolute numbers of tetramer-positive $T$ cells in the livers of the two strains of mice had patterns similar to the percentage of change (data not shown). Therefore, the Th1-type shift after $\alpha$ GalCer injection in adult NZB/W mice is not due to a profound or prolonged depletion of NKT cells as compared with C57BL/6 mice.

Treatment with $\alpha$ GalCer worsens lupus in adult $N Z B / W$ mice. Treatment with $\alpha$ GalCer induced Th2-type immune responses in NOD and adult C57BL/6 mice and ameliorated autoimmune diabetes and EAE (34, $35,37)$. Since $\alpha$ GalCer administration induced a Th1type immune response in NZB/W mice at age 8-12 weeks, we expected $\alpha$ GalCer given to prenephritic $\mathrm{NZB} / \mathrm{W}$ mice would also induce Th1-type immune responses and accelerate lupus development. Accordingly, groups of 15 female NZB/W mice at age 20 weeks were injected with $\alpha \mathrm{GalCer}$ or PBS/vehicle control twice a week for 2 weeks. All the mice were monitored weekly for proteinuria and survival. Serum samples were collected monthly, starting at age 26 weeks, an expected time for the onset of proteinuria $(15,46)$.

As shown in Figure 4, $a$ and b, all the mice in the PBS/vehicle control group developed proteinuria by 39 weeks of age. In contrast, all the mice in the $\alpha$ GalCertreated group developed proteinuria by 32 weeks of age. The $\alpha$ GalCer treatment accelerated the onset of proteinuria by about 7 weeks $(P=0.002)$. Similarly, when the survival of the groups was compared, $\alpha$ GalCer treatment shortened the survival by about 14 weeks as compared with PBS/vehicle control (49 versus 35 weeks for all mice to die; $P=0.0007)$.

Serum samples from the control and experimental groups at 26 weeks of age were measured for levels of IgE, IgG2a, and IgG2a anti-dsDNA Ab's. Later time points were not compared due to the rapid development of lupus and death in the $\alpha$ GalCer-treated group. As shown in Figure 4, c-e, $\alpha$ GalCer-treated mice had a significant decrease in serum $\operatorname{IgE}(P<0.01)$, but about a twofold increase in serum IgG2a and IgG2a anti-dsDNA Ab's $(P<0.001)$ as compared with PBS/vehicle control. These results demonstrated that $\alpha$ GalCer treatment not only augments the Th1-type immune responses but also worsens lupus in NZB/W mice. It is possible that $\alpha \mathrm{GalCer}$ may worsen lupus by 
stimulating $B$ cells that express surface CD1d to secrete $\mathrm{Ab}$ 's by binding to the CD1d. $\alpha$ GalCer did not, however, significantly change the in vitro secretion of IgM autoantibodies by sorted $\mathrm{B} 220^{+} \mathrm{CD} 1 \mathrm{~d}^{\text {high }} \mathrm{B}$ cells from the spleen of 8- to 12 -week-old NZB/W mice as compared with vehicle control (culture supernatant IgM concentration, $\alpha$ GalCer: $1,647 \pm 76$ versus vehicle $1,492 \pm 96 \mu \mathrm{g} / \mathrm{ml})$. This indicated that $\alpha \mathrm{GalCer}$ did not directly activate the $\mathrm{CD} 1 \mathrm{~d}^{\text {high }} \mathrm{B}$ cells.

Anti-CD1d mAb treatment induces a Th2-type shift and ameliorates lupus in adult NZB/W mice. Since activation of the NKT cells augmented Th1-type immune responses and worsened lupus in adult NZB/W mice, we tested whether treatment with a blocking antiCD1d mAb would induce a Th2-type shift and ameliorate lupus. We reported recently that a short-term treatment (1 month) of NZB/W mice with anti-CD1d $\mathrm{mAb}$ delayed the onset of lupus for 4-8 weeks, but the pattern of immune response was not investigated (20). In the current study, groups of 20 female $\mathrm{NZB} / \mathrm{W}$ mice (8 weeks old) were injected with anti$\mathrm{CD} 1 \mathrm{~d} \mathrm{mAb}$ or rat IgG2b isotype control $(500$ $\mu \mathrm{g} /$ mouse) daily for the first 3 days, then twice a month for 6 months. As in the $\alpha$ GalCer treatment experiments, all the mice were monitored weekly for proteinuria and survival. Serum samples were collected monthly, starting at 26 weeks of age. As shown in Figure 4, a and b, all the mice in the PBS/vehicle

control group developed proteinuria by 39 weeks of age, and all the mice in the control rat IgG2b-treated group developed proteinuria by 53 weeks of age. In contrast, all the mice in the anti-CD1d mAb-treated group developed proteinuria by 72 weeks of age. As compared with PBS/vehicle control or rat IgG2b control, anti$\mathrm{CD} 1 \mathrm{~d} \mathrm{mAb}$ treatment delayed the onset of proteinuria 33 weeks $(P<0.0001)$ or 19 weeks $(P=0.03)$, respectively (Figure 4, a and b).

Similarly, when the survival of the groups was compared, anti-CD1d treatment prolonged the survival 23 weeks as compared with PBS/vehicle control (72 versus 49 weeks for all mice to die, $P<0.0001$ ) or by 16 weeks as compared with rat IgG2b isotype controls (72 versus 56 weeks for all mice to die, $P=0.006$ ). These results indicate that long-term ( 6 month) antiCD1d treatment can also achieve a more prolonged amelioration of lupus as compared with the shortterm ( 1 month) treatment used in our previous report (20). IgG2b isotype treatment significantly delayed the onset of proteinuria and prolonged survival as compared with PBS/vehicle control $(P<0.01)$. This may be due to the local anti-inflammatory activity mediated by inhibitory $\mathrm{Fc} \gamma$ receptor IIB when large amounts of IgG2b are infused $(48,49)$. Rat IgG2b treatment did not change serum levels of pathogenic IgG2a anti-dsDNA as compared with the PBS/vehicle control (Figure 4e).
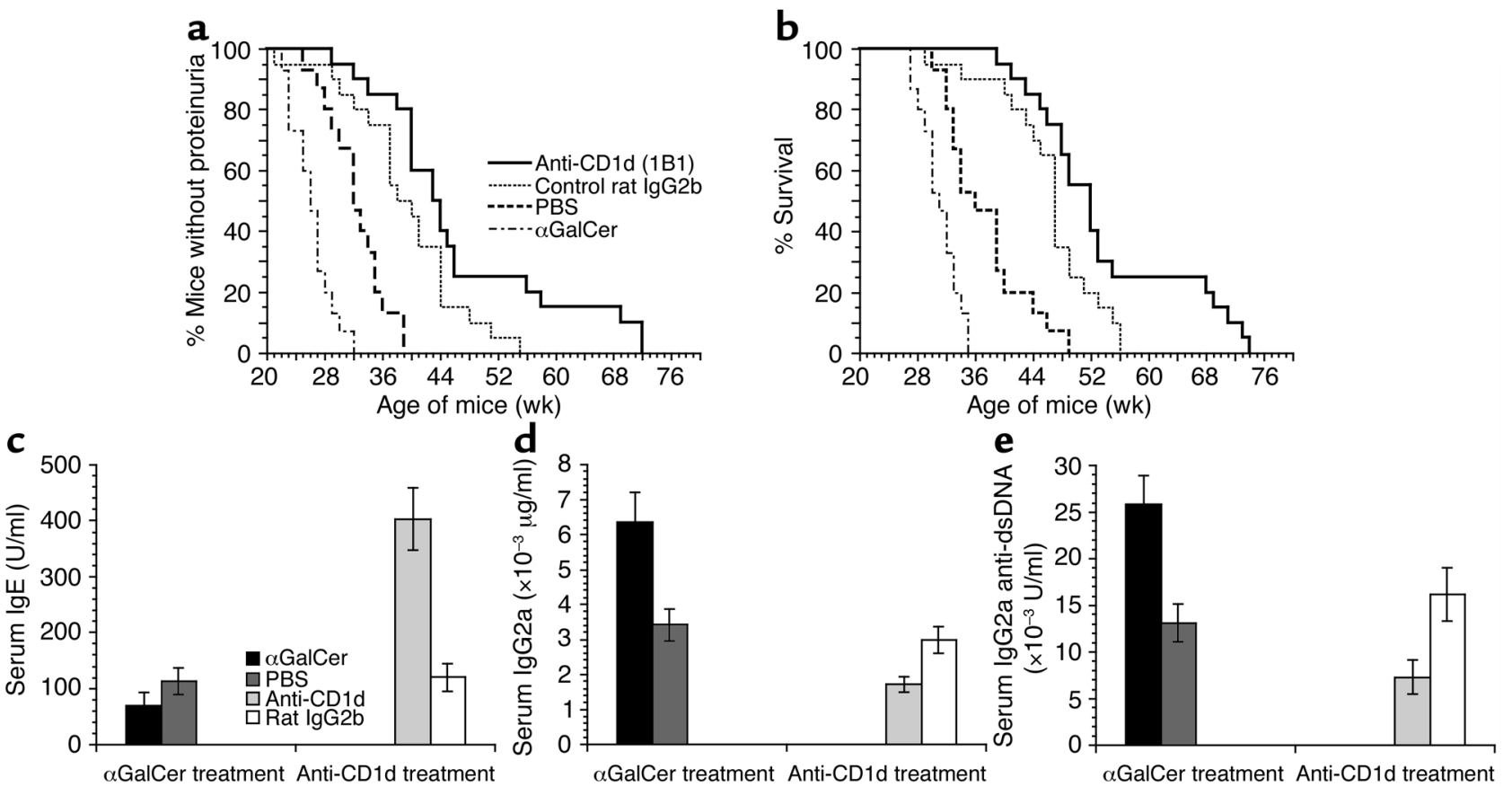

\section{Figure 4}

Exacerbation or amelioration of lupus by $\alpha \mathrm{GalCer}$ or anti-CD1d mAb treatment in adult NZB/W mice. NZB/W mice were treated with $\alpha \mathrm{Gal}-$ Cer, PBS/vehicle, anti-CD1d mAb, and rat IgG2b isotype control. (a and $\mathbf{b}$ ) Groups of 20-week-old NZB/W mice were given four injections of $\alpha \mathrm{GalCer}$ or PBS/vehicle control at a dose of $4 \mu \mathrm{g} /$ mouse over a period of 2 weeks. There were 15 mice in each group. In addition, groups of 8- to 12-week-old NZB/W mice were given 15 injections of anti-CD1d mAb or control rat IgG2b at a dose of $500 \mu \mathrm{g} / \mathrm{mouse}$ over a period of 6 months (five injections for the first month, two injections for each month thereafter). There were 20 mice in each group. All mice were monitored weekly for proteinuria (a) and survival (b). (c-e) The serum concentrations of IgE, IgG2a, and IgG2a anti-dsDNA Ab's of the above-treated mice at the age of 26 weeks. Bars show means of 15 or 20 mice, and brackets show standard errors. 

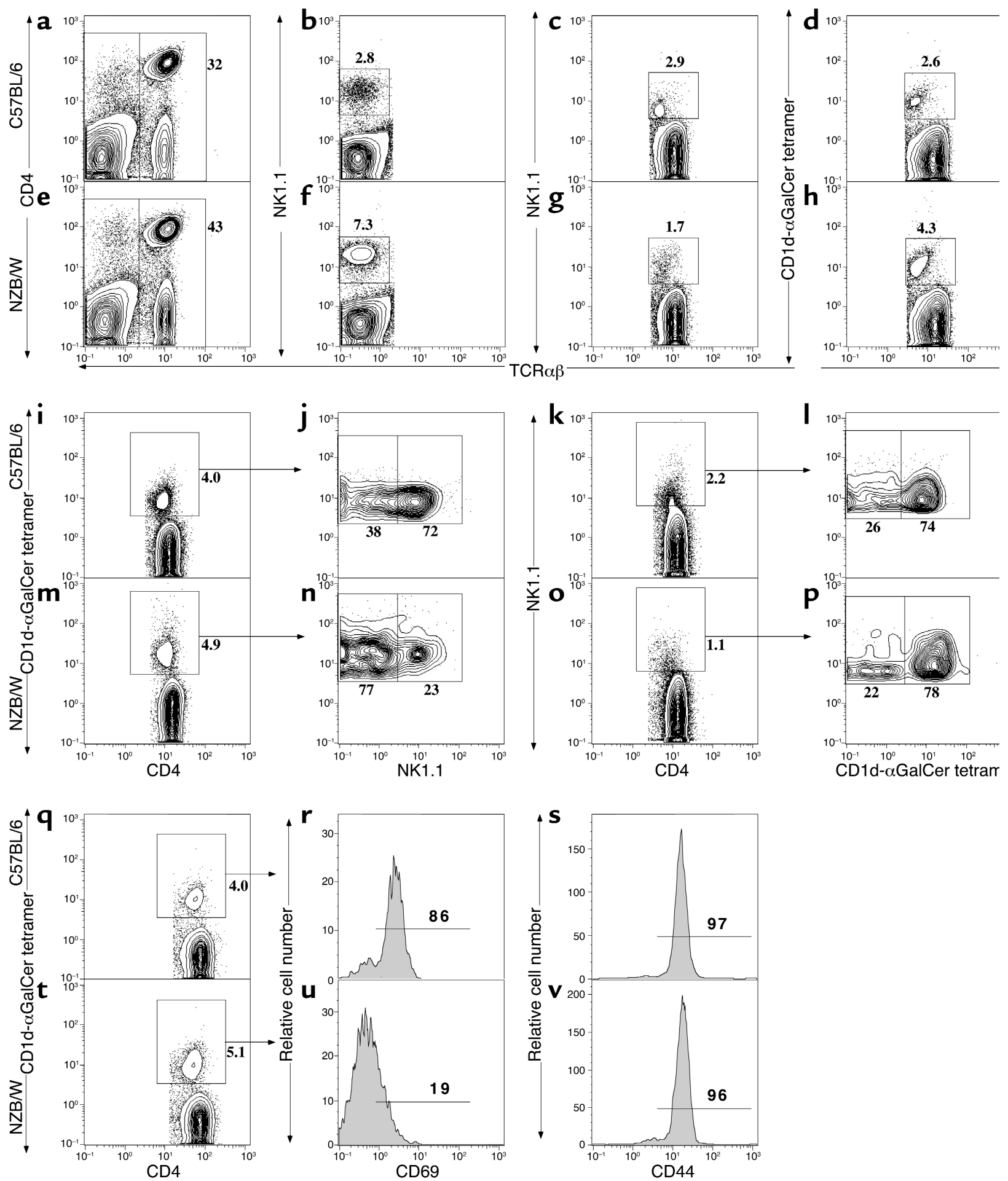

\section{Figure 5}

Multicolor flow-cytometric analyses of spleen cells. Spleen cells from 8- to 12-week-old C57BL/6 and NZB/W mice were stained with anti-TCR $\alpha \beta, C D 4, N K 1.1$, and CD1d- $\alpha$ GalCer tetramer. (a and $\mathbf{e})$ Staining of CD4 versus TCR $\alpha \beta$ for both strains. (b and $\mathbf{f})$ NK1.1 versus TCR $\alpha \beta$ on gated TCR $\alpha \beta^{-}$cells. (c and $\mathbf{g}$ ) NK1.1 versus TCR $\alpha \beta$ on gated TCR $\alpha \beta^{+}$cells. ( $\mathbf{d}$ and $\mathbf{h}$ ) Tetramer versus TCR $\alpha \beta$ on gated TCR $\alpha \beta^{+}$cells. (i and $\mathbf{m}$ ) gated TCR $\alpha \beta^{+} \mathrm{CD} 4^{+}$T cells were analyzed for CD4 versus tetramer. ( $\mathbf{j}$ and $\mathbf{n}$ ) Tetramer versus NK1.1 on gated TCR $\alpha \beta^{+}$CD $4{ }^{+}$tetramer-positive cells. ( $\mathbf{k}$ and $\left.\mathbf{o}\right)$ NK1.1 versus CD4 on the gated TCR $\alpha \beta^{+} C D 4^{+}$cells. (I and $\mathbf{p}$ ) NK1.1 versus tetramer on the gated TCR $\alpha \beta^{+} \mathrm{CD} 4^{+} \mathrm{NK} 1.1^{+}$cells. The percentage of each subset was shown beside the gating box. Data were representative of six mice in each strain. ( $\mathbf{q}$ and $\mathbf{t})$ Gated TCR $\alpha \beta^{+} \mathrm{CD} 4{ }^{+} \mathrm{T}$ cells were analyzed for CD4 versus tetramer. ( $\mathbf{r}$ and $\left.\mathbf{s}\right)$ Expression of CD69 and CD44, respectively, on the gated C57BL/ 6 cells and ( $\mathbf{u}$ and $\mathbf{v}$ ) expression of CD69 and CD44 on the gated NZB/W cells. The background staining with control CD1d-vehicle-tetramer for the gated T cells was less than $0.1 \%$. 
Serum samples from the anti-CD1d $\mathrm{mAb}$ and isotype control-treated groups at 26 weeks of age were also measured for levels of IgE, IgG2a, and IgG2a antidsDNA Ab's. As shown in Figure 4, c-e, the anti-CD1dtreated group had a fourfold increase in $\operatorname{IgE}(P<0.0001)$ and a twofold decrease in serum IgG2a and antidsDNA IgG2a Ab's $(P<0.01)$ as compared with the rat IgG2b isotype control-treated group. As reported previously, in vivo anti-CD1d mAb treatment did not significantly change the percentage of total $\mathrm{B}$ cells among spleen cells or CD1d high B cells among total B cells and did not reduce the serum levels of IgM and IgM antidsDNA Ab's $(20,50)$. These results indicate that antiCD1d mAb treatment induces a Th2-type shift of serum Ig's and ameliorates lupus in NZB/W mice. The marked improvement of lupus by anti-CD1d mAb treatment as compared with PBS controls is likely due to both the specific reduction of pathogenic IgG2a anti-dsDNA Ab's and the nonspecific Fc $\gamma$ receptor IIB-mediated inhibition of local inflammation activity after IgG infusion $(48,49)$.

The majority of CD1d-reactive tetramer-positive Tcells in the $N Z B / W$ spleen are NK1.1- . We compared the percentage and absolute numbers of NK1.1 $1^{+} \mathrm{T}$ cells and $\mathrm{T}$ cells expressing the CD1d-reactive invariant Vo14Jo281TCRs, as judged by staining with a CD1d- $\alpha$ GalCer tetramer reagent in 8- to 12 -week-old C57BL/6 and NZB/W mice. About $32 \%$ of C57BL/ 6 spleen cells (Figure $5 \mathrm{a}$ ) and $43 \%$ of NZB/W spleen cells (Figure 5e) were TCR $\alpha \beta^{+}$. The mean (plus or minus SE) percentage in six C57BL/ 6 and six $\mathrm{NZB} / \mathrm{W}$ mice was $30 \% \pm 3 \%$ and $38 \% \pm 5 \%$, respectively. To determine whether NK1.1 expression on conventional NK cells was similar in NZB/W and C57BL/ 6 mice, gated TCR $\alpha \beta^{-}$spleen cells from both strains were analyzed for the staining of NK1.1. Figure 5, b and $\mathrm{f}$, show that $2.8 \%$ of the TCR $\alpha \beta^{-}$cells in the C57BL $/ 6$ spleen were NK1.1 $1^{+}$cells (mean $3 \% \pm 1.5 \%$ ), and $7.3 \%$ of the TCR $\alpha \beta^{-}$cells in NZB/W spleen were NK1.1+ (mean $9 \% \pm 2 \%$ ). The intensity of NK1.1 staining was similar. Gated TCR $\alpha \beta^{+} \mathrm{T}$ cells were also analyzed for staining of NK1.1 (Figure 5, $\mathrm{c}$ and $\mathrm{g}$ ) and for staining with the CD1d- $\alpha$ GalCer tetramer reagent (Figure $5, d$ and $h$ ). The percentage of NK1.1 $1^{+} \mathrm{T}$ cells among TCR $\alpha \beta^{+} \mathrm{T}$ cells was reduced in the NZB/W spleen (1.7\%) (mean $1.6 \% \pm 0.4 \%$ ) as compared with the $\mathrm{C} 57 \mathrm{BL} / 6$ spleen $(2.9 \%)$ (mean $3.4 \% \pm 0.3 \%$ ). On the other hand, the percentage of tetramer-positive $\mathrm{T}$ cells was increased in NZB/W spleen $(4.3 \%)$ (mean $4.8 \% \pm 0.9 \%$ ) as compared with the C57BL $/ 6$ spleen $(2.6 \%)$ (mean $3.5 \% \pm 0.5 \%$ ). The gated T cells from Ja281-/- C57BL/6 spleens had less than $0.1 \%$ tetramer-positive $\mathrm{T}$ cells (data not shown). The absolute number of NK1.1 $1^{+} \mathrm{T}$ cells in C57BL/ 6 spleen (mean 899 $\pm 39 \times 10^{3}$ ) was about twofold higher than that in $\mathrm{NZB} / \mathrm{W}$ spleen $\left(\right.$ mean $\left.480 \pm 67 \times 10^{3}\right)$. The difference was significant $(P<0.01)$.

The absolute number of tetramer-positive $T$ cells in the spleen of $\mathrm{C} 57 \mathrm{BL} / 6$ and $\mathrm{NZB} / \mathrm{W}$ mice was similar $\left(923 \pm 72 \times 10^{3}\right.$ and $989 \pm 88 \times 10^{3}$, respectively; $\left.P>0.1\right)$. Approximately $80 \%$ of the tetramer-positive T cells and
$60 \%$ of the NK1.1 $1^{+} \mathrm{T}$ cells in the spleen of both strains were $\mathrm{CD}^{+} \mathrm{T}$ cells (data not shown). As shown in Figure 5 , $\mathrm{i}-\mathrm{p}$, while $72 \%$ of gated $\mathrm{CD}^{+}$tetramer-positive $\mathrm{T}$ cells in the spleen of C57BL/6 and NZB/W were NK1.1 (mean $71 \% \pm 4 \%$ ), only $23 \%$ of those from NZB/W spleen were NK1.1 $1^{+}$(mean $20 \% \pm 5 \%$ ). Conversely, $74 \%$ of $\mathrm{CD} 4{ }^{+} \mathrm{NK} 1.1^{+} \mathrm{T}$ cells in the $\mathrm{C} 57 \mathrm{BL} / 6$ spleen were tetramer positive (mean $75 \% \pm 4 \%$ ), and $78 \%$ of $\mathrm{CD} 4^{+} \mathrm{NK} 1.1^{+} \mathrm{T}$ cells from $\mathrm{NZB} / \mathrm{W}$ spleen were tetramer positive (mean $78 \% \pm 6 \%$ ). These results indicate that there is no reduction of the invariant CD1d-reactive $\mathrm{T}$ cells in the spleen of 8- to 12 -week-old NZB/W mice as
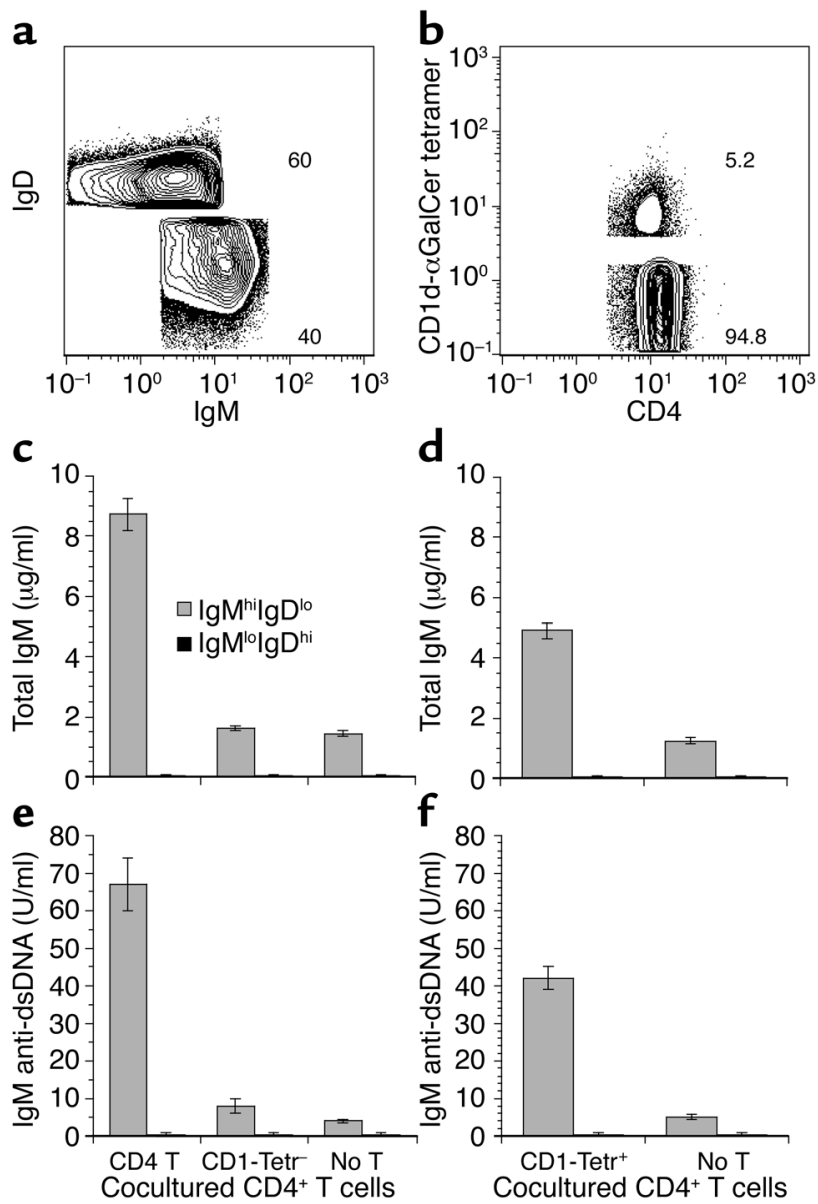

\section{Figure 6}

CD1d- $\alpha$ GalCer tetramer-positive $C D 4^{+} T$ cells augment in vitro secretion of IgM anti-dsDNA Ab's. (a) Spleen B cells (CD19+ gated) from 8- to 12-week-old NZB/W mice were sorted into $\lg \mathrm{M}^{\text {high }} / g \mathrm{D}^{\text {low }}$ and Ig $M^{\text {low }} / g D^{\text {high }} B$ cell subsets. (b) Spleen $C D 4^{+} T$ cells $\left(T C R \alpha \beta^{+} C D 4^{+}\right.$ gated) were sorted into $C D 1 d-\alpha G a l C e r$ tetramer-positive and CD1d$\alpha G$ alCer tetramer-negative subsets. (c and $\mathbf{e}$ ) Concentrations of IgM and IgM anti-dsDNA Ab's in the culture supernatants of sorted CD4 ${ }^{+}$ $T$ cells or tetramer-negative CD4 ${ }^{+} \mathrm{T}$ cells $\left(500 \times 10^{3} \mathrm{each}\right)$ cocultured with sorted $\lg M^{\text {high }} \lg D^{\text {low }} B$ or $\lg M^{\text {low }} \mid g D^{\text {high }} B$ cells $\left(200 \times 10^{3}\right.$ each $)$ in vitro for 5 days. (d and $\mathbf{f}$ ) Concentrations of $\operatorname{IgM}$ and $\operatorname{IgM}$ antidsDNA Ab's in the culture supernatants of sorted CD1d- $\alpha$ GalCer tetramer-positive $\mathrm{CD} 4^{+} \mathrm{T}$ cells $\left(50 \times 10^{3}\right)$ cocultured with $200 \times 10^{3}$ $\lg \mathrm{M}^{\text {high }} \mid g \mathrm{D}^{\text {low }}$ or $\lg \mathrm{M}^{\text {low }} \mid \mathrm{gD} \mathrm{D}^{\text {high }} \mathrm{B}$ cells for 5 days. Bars show means of quadruple cultures from three replicate experiments, and brackets show standard errors. lo, low; hi, high; Tetr-, tetramer negative; Tetr', tetramer positive; $\mathrm{T}, \mathrm{T}$ cells. 
compared with C57BL/ 6 mice, and the majority of the CD1d-reactive T cells in NZB/W spleen are NK1.1'.

Since tetramer-positive NK1.1-CD4 ${ }^{+} \mathrm{T}$ cells in the $\mathrm{NZB} / \mathrm{W}$ spleen may represent immature NKT cells similar to those found in the thymus of nonautoimmune mice (51-53) or mature NKT cells that have downregulated the NK1.1 surface receptors after spontaneous activation (54), we attempted to distinguish these two possibilities by examining additional surface receptors and the cytokine secretion patterns of the tetramer-positive $\mathrm{CD}^{+} \mathrm{T}$ cells in $\mathrm{C} 57 \mathrm{BL} / 6$ and NZB/W mice. Figure $5, t-v$, shows that the tetramer-positive $\mathrm{CD}^{+} \mathrm{T}$ cells in adult NZB/W mice express low levels of CD69 and a discrete high level of CD44. This pattern is atypical of mature NKT cells that express high levels of both markers (51-53). The typical pattern was observed in the tetramer-positive $\mathrm{CD} 4^{+} \mathrm{T}$ cells from the adult $\mathrm{C} 57 \mathrm{BL} / 6$ spleen (Figure 5, q-s). The NZB/W pattern, however, is not typical of immature NK1.1- tetramer-positive $\mathrm{T}$ cells, since the latter cells express low levels of CD69, but are heterogeneous for CD44 expression (53).

In further experiments, $5 \times 10^{3}$ sorted tetramer-positive $\mathrm{CD}^{+}$and tetramer-positive NK1.1- ${ }^{-} \mathrm{CD} 4^{+} \mathrm{T}$ cells from the spleen of $\mathrm{NZB} / \mathrm{W}$ mice were stimulated in vitro with PMA and ionomycin, and the cytokine pattern in culture supernatants was analyzed for the concentrations of IL- 4 and IFN- $\gamma$ after 48 hours. A similar analysis was performed on C57BL/ 6 tetramer-positive $\mathrm{CD}^{+} \mathrm{T}$ cells. At this cell number, spontaneous secretion of cytokines was not detectable using NZB/W or C57BL/6 mice. Whereas the mean (plus or minus SE) concentrations of IFN- $\gamma$ and IL-4 from quadruplicate cultures were $23 \pm 2$ and $630 \pm 53 \mathrm{pg} / \mathrm{ml}$, respectively, using all NZB/W tetramer-positive $\mathrm{CD} 4^{+} \mathrm{T}$ cells, the mean concentrations using NZB/W tetramer-positive NK1.1 ${ }^{-} \mathrm{CD} 4^{+} \mathrm{T}$ cells were $48 \pm 7$ and $1,786 \pm 78 \mathrm{pg} / \mathrm{ml}$, respectively. On a per cell basis, the concentrations of both IFN- $\gamma($ mean $21 \pm 2)$ and IL-4 $(323 \pm 15)$ were lower when $\mathrm{C} 57 \mathrm{BL} / 6$ tetramer-positive $\mathrm{CD}^{+} \mathrm{T}$ cells were used instead of the NZB/W tetramer-positive NK1.1 ${ }^{-} \mathrm{CD} 4^{+} \mathrm{T}$ cells. The more vigorous secretion of IFN- $\gamma$ by the NZB/W tetramer-positive NK1.1- $\mathrm{T}$ cells is more characteristic of mature rather than immature NKT cells $(51,53)$. The very high level of IL-4 is atypical of mature cells (51-53), however.

CD1d-reactive tetramer-positive $\mathrm{CD}^{+} \mathrm{T}$ cells are required for the augmentation of in vitro secretion of IgM anti-dsDNA Ab's by $\mathrm{CD}^{+}{ }^{+} \mathrm{T}$ cells in $\mathrm{NZB} / \mathrm{W}$ mice. We have reported that $\mathrm{CD} 1 \mathrm{~d}^{\text {high }} \mathrm{B}$ cells are the predominant source of spontaneous secretion of IgM antidsDNA Ab's by splenic B cells in NZB/W mice, and CD4 ${ }^{+}$ $T$ cells augment the $A b$ secretion (20). In the current study, we determined whether the CD1d-reactive $\mathrm{CD} 4^{+}$ $\mathrm{T}$ (CD1d- $\alpha$ GalCer tetramer-positive) cells were required for the augmentation. As shown in Figure 6, splenic B cells $\left(\mathrm{CD} 19^{+}\right.$gated) from 8- to 12 -week-old NZB/W mice were sorted into $\operatorname{IgM}^{\text {high }} \operatorname{IgD}^{\text {low }}$ and $\operatorname{IgM}^{\text {low }} \operatorname{IgD}^{\text {high }} \mathrm{B}$ cells (Figure 6a). Previous studies have shown that the former $B$ cell subset is CD1d high and the latter is $C D 1 d^{10 w}(55$,
56). The $\mathrm{CD}^{+} \mathrm{T}$ cells from the same spleens were sorted into tetramer-positive and tetramer-negative cells (Figure 6b). Since tetramer staining may activate the NKT cells by cross-linking the invariant V $\alpha 14 J \alpha 281 T C R s$, we first tested if depletion of tetramer-positive $\mathrm{T}$ cells removed the capacity of $\mathrm{CD} 4^{+} \mathrm{T}$ cells to augment in vitro secretion of autoantibodies. Sorted $\mathrm{IgM}^{\text {high }} \mathrm{IgD}$ low or $\operatorname{IgM}^{\text {low }} \operatorname{IgD}{ }^{\text {high }} \mathrm{B}$ cells $\left(200 \times 10^{3}\right)$ were cultured alone or cocultured with $500 \times 10^{3}$ total $\mathrm{CD}^{+} \mathrm{T}$ cells or tetramernegative $\mathrm{CD}^{+} \mathrm{T}$ cells in vitro for 5 days. The supernatants were assayed for the concentrations of IgM and IgM anti-dsDNA Ab's.

In Figure 6, $\mathrm{c}$ and $\mathrm{e}, \mathrm{IgM}^{\text {high }} \mathrm{IgD} \mathrm{D}^{\text {low }} \mathrm{B}$ cells alone secreted about $1.5 \mu \mathrm{g} / \mathrm{ml}$ of IgM and $4 \mathrm{U} / \mathrm{ml}$ of IgM antidsDNA Ab's, but IgM ${ }^{\text {low }} \operatorname{IgD}{ }^{\text {high }} \mathrm{B}$ cells alone did not secrete detectable amounts of IgM or IgM anti-dsDNA $\mathrm{Ab}$ 's. The addition of total $\mathrm{CD} 4^{+} \mathrm{T}$ cells augmented the secretion of IgM by $\operatorname{IgM}^{\text {high }} \operatorname{IgD}^{\text {low }} \mathrm{B}$ cells about fivefold and IgM anti-dsDNA Ab's about 15 -fold $(P<0.001)$. Total CD4 ${ }^{+} \mathrm{T}$ cells did not help the IgM ${ }^{\text {low }}{ }^{\prime g} D^{\text {high }} \mathrm{B}$ cells to secrete Ab's (Figure 6, c and e), however. Sorted tetramer-negative $\mathrm{CD}^{+}{ }^{+} \mathrm{T}$ cells (accounting for $95 \%$ of total $\mathrm{CD}^{+}{ }^{+} \mathrm{T}$ cells) lost the capacity to significantly aug-

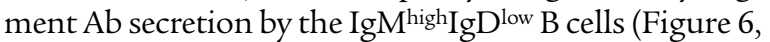
$c$ and e; $P>0.1)$. In addition, the sorted tetramer-positive $\mathrm{CD} 4^{+} \mathrm{T}$ cells $\left(50 \times 10^{3}\right)$ augmented the secretion of IgM threefold $(P<0.01)$ and IgM anti-dsDNA tenfold $(P<0.001)$ as compared with $\mathrm{IgM}^{\text {high }} \operatorname{IgD}{ }^{\text {low }} \mathrm{B}$ cells alone (Figure 6, d and f). On the other hand, depletion of the NK1.1 $1^{+} \mathrm{CD} 4^{+} \mathrm{T}$ cells (about $1.5 \%$ ) from total $\mathrm{CD} 4^{+} \mathrm{T}$ cells did not significantly reduce the augmentation of the $\mathrm{Ab}$ secretion by total $\mathrm{CD} 4^{+} \mathrm{T}$ cells (data not shown). These results indicate that the tetramer-positive (but not NK1.1 $\left.1^{+}\right) \mathrm{CD}^{+} \mathrm{T}$ cells are required for the augmentation of in vitro spontaneous secretion of IgM and IgM anti-dsDNA autoantibodies. Addition of anti-CD1d $m A b$, or anti-IL-4 mAb, or anti-IFN- $\gamma \mathrm{mAb}$, or anti-IL-4 and anti-IFN- $\gamma \mathrm{mAb}$ in the culture of $\mathrm{CD}^{+} \mathrm{T}$ and $\mathrm{IgM}^{\text {high }} \mathrm{IgD}^{\text {low }} \mathrm{B}$ cells, however, failed to significantly block the augmentation by $\mathrm{CD}^{+} \mathrm{T}$ cells (data not shown). This may be due to spontaneous in vivo activation of CD1d high $B$ cells and CD1d-reactive T cells in $\mathrm{NZB} / \mathrm{W}$ mice such that augmentation in vitro is by activation-dependent cytokines (other than IL-4 and IFN- $\gamma$ ) and/or costimulatory molecules, since our previous studies showed that in vitro activation of nonautoimmune BALB/c B cells by CD1d-reactive transgenic $\mathrm{T}$ cells was blocked by the same anti-CD1d mAb (8).

We also tried to determine whether sorted tetramerpositive $\mathrm{CD}^{+} \mathrm{T}$ cells could augment the in vitro spontaneous secretion of IgG and IgG anti-dsDNA Ab's by splenic B cells in older NZB/W mice. Splenic B cells from 8- to 12-week-old NZB/W mice spontaneously secrete little IgG or IgG anti-dsDNA Ab's in vitro (20), but those from 24- to 28-week-old NZB/W mice with proteinuria secrete large amounts of IgG and IgG antidsDNA Ab's in vitro (20). We used the sorted $\mathrm{B} 220^{+}$cells from 24- to 28-week-old NZB/W as the B cell source for those in vitro cultures. We found that, although both 
total $\mathrm{CD} 4^{+} \mathrm{T}$ and tetramer-positive $\mathrm{CD} 4^{+} \mathrm{T}$ cells significantly augmented the IgM and IgM anti-dsDNA secretion, neither total $\mathrm{CD} 4^{+} \mathrm{T}$ cells nor tetramer-positive $\mathrm{CD}^{+} \mathrm{T}$ cells augmented the in vitro secretion of $\mathrm{IgG}$ or IgG anti-dsDNA Ab's (data not shown).

\section{Discussion}

Hereditary lupus of NZB/W mice is an Ab-mediated systemic autoimmune disease in which the Th1 cytokine IFN- $\gamma$ has been shown to play an important role in the pathogenesis of tissue injury (57). Anti-IFN- $\gamma$ $\mathrm{mAb}$ treatment has been reported to ameliorate the immune complex glomerulonephritis, the hallmark of the disease (21). In addition, introduction of a transgene encoding the Th2 cytokine IL-4 into lupus-prone $\left(\mathrm{NZW} \times \mathrm{C} 57 \mathrm{BL} / 6\right.$.Yaa) $\mathrm{F}_{1}$ mice prevented lupus development (58). We have recently reported that adoptive transfer of CD1d-reactive transgenic CD4 $\mathrm{T}$ cells with a Th1-like cytokine-secretion pattern induced lupus in $\mathrm{BALB} / \mathrm{c} n u / n u$ recipients (8). CD1d-reactive $\mathrm{T}$ cells have also been suggested to play a role in augmenting IgG2a anti-dsDNA secretion and lupus development in lupusprone NZB/W mice (20). It is not yet clear, however, whether activation of the CD1d-reactive $T$ cells in $\mathrm{NZB} / \mathrm{W}$ mice contributed to the IFN- $\gamma$ secretion that shifted the autoantibody secretion toward the pathogenic IgG2a isotype.

In vivo activation of NKT cells with $\alpha$ GalCer treatment over a 2-week interval induced Th2-type immune responses with high levels of serum IgE in C57BL/6, $\mathrm{BALB} / \mathrm{c}$, and NOD mice and ameliorated autoimmune diabetes in NOD mice $(33,35)$. In the current study, we used a 2 -week $\alpha$ GalCer regimen at a similar dose (4 $\mu \mathrm{g} /$ mouse) to treat 8- to 12 -week-old NZB/W mice that have already developed IgM anti-dsDNA Ab's (46). These NZB/W mice treated with $\alpha$ GalCer developed increased levels of IFN- $\gamma$ and decreased levels of IL- 4 in serum as compared with the treated C57BL/ 6 mice. This Th1-like serum cytokine profile in the treated $\mathrm{NZB} / \mathrm{W}$ mice was associated with decreased levels of serum IgE and increased levels of serum IgG2a and IgG2a anti-dsDNA autoantibodies. The in vivo $\alpha$ GalCer-induced Th1 immune response was age related, since 4-week-old NZB/W mice injected with $\alpha$ GalCer showed a significant elevation of serum IL-4 but not IFN- $\gamma$. Thus, the young NZB/W mice showed a Th2 pattern that 1-2 months later shifted to a Th1 pattern at about the time of anti-dsDNA development. The levels of serum IL-4 in the young mice were, however, below the levels of serum IL-4 in the older mice after $\alpha$ GalCer treatment. This may be related to the lower absolute numbers of NKT cells in the spleen of young $\mathrm{NZB} / \mathrm{W}$ mice that were about two-thirds of that in the older mice (data not shown). The $\alpha$ GalCer treatment of young NZB/W mice did not have a significant impact on the tempo of the progressive increase in levels of IgG2a anti-dsDNA Ab's and the development of proteinuria that are the hallmarks of lupus disease activity over a subsequent 8 -month observation period.
The same treatment, however, accelerated the development of lupus in adult NZB/W mice as judged by earlier onset of proteinuria and mortality than that which occurred in PBS/vehicle-treated mice. These results indicate that in vivo activation of NKT cells in adult $\mathrm{NZB} / \mathrm{W}$ mice with this $\alpha \mathrm{GalCer}$ regimen contributes to IFN- $\gamma$ secretion and autoantibody isotype switching to IgG2a. These results also link the Th1-type immune responses and lupus disease activity in adult NZB/W mice. It is of interest that coinjection of $\alpha \mathrm{GalCer}$ and myelin basic protein augmented Th1-type immune responses and exacerbated EAE in B10.PL mice, but the same treatment augmented Th2-type immune responses and prevented EAE in C57BL/6 mice (37). Thus, some autoimmune-prone strains of mice can differ from other autoimmune or nonautoimmune strains in the pattern of immune responses observed after NKT cell activation in vivo, such that autoimmune disease may be ameliorated or exacerbated. We did not examine different doses, dosing schedules, or durations of $\alpha$ GalCer treatment other than the one reported herein. It is possible that more extended $\alpha$ GalCer treatment regimens (34), alternative synthetic glycolipid regimens (59), or daily (35) rather than twice weekly injections that have been used to ameliorate autoimmune diabetes might result in a different outcome of disease activity in lupus.

Sorted NKT cells from the adult NZB/W and C57BL/6 spleen activated with PMA and Ionomycin secreted similar amounts of IFN- $\gamma$ in vitro, but NZB/W NKT cells secreted fivefold higher amounts of IL-4 as compared with C57BL/6 mice, indicating a Th2-type cytokine profile. Thus, there is a discrepancy between cytokine profiles generated after $\alpha$ GalCer stimulation in vivo versus in vitro in NZB/W mice. Pure populations of NKT cells in NZB/W mice may be Th2-biased instead of Th1biased. NK cells, however, present in higher levels in $\mathrm{NZB} / \mathrm{W}$ as compared with C57BL/6 mice, may contribute to the higher serum levels of IFN- $\gamma$ in NZB/W mice after $\alpha$ GalCer treatment in vivo. IFN- $\gamma$ from the activated NKT cells have been found to initiate the activation and IFN- $\gamma$ secretion of NK cells 90 minutes after $\alpha$ GalCer injection (60), and IFN- $\gamma$ from NK cells was reported to enhance isotype switching to $\operatorname{IgG2a}(61,62)$. It has also been reported that NKT cells can modulate the cytokine secretion capacity of dendritic cells $(38,63)$.

In the current study, adult NZB/W mice treated with a 6-month course of anti-CD1d mAb had increased serum levels of IgE and decreased levels of serum IgG2a and IgG2a anti-dsDNA Ab's as compared with controls. This treatment significantly delayed the onset of proteinuria and mortality. The reduced serum levels of IgG2a Ab after anti-CD1d treatment suggests that suppression of in vivo spontaneous IFN- $\gamma$ secretion occurs after blocking activation of CD1d-reactive NKT cells. It is not yet clear, however, whether the spontaneous IFN- $\gamma$ secretion is directly from NKT cells themselves or from other cells such as NK cells.

The majority of the CD1 $\alpha$ GalCer tetramer-positive $T$ cells in the NZB/W spleen were NK1.1', although the 
majority of the tetramer-positive cells were NK1.1 ${ }^{+}$in C57BL/6 mice. The reduction of NK1.1 expression on tetramer-positive $\mathrm{T}$ cells may be explained by the downregulation of NK1.1 markers on the spontaneously activated tetramer-positive $T$ cells in vivo. NKT cells have been reported to lose the NK1.1 marker after in vitro activation (54). On the other hand, tetramer-positive NK1.1- $\mathrm{T}$ cells in the thymus of nonautoimmune mice have been reported to be the immature precursors of the NK1.1 ${ }^{+}$tetramer-positive T cells (51-53). To determine whether the majority of NK1.1- tetramer-positive T cells in the spleen of $\mathrm{NZB} / \mathrm{W}$ were the immature type, we analyzed additional surface markers and their cytokine secretion pattern. Although these cells expressed low levels of CD69, they expressed homogeneous high levels of CD44, a pattern that is atypical for either mature or immature NKT cells (51-53). Analysis of cytokine secretion showed that the NK1.1- tetramer-positive CD4 T cells in the NZB/W spleen made more IFN- $\gamma$ and IL-4 than mature tetramer-positive NKT cells in the spleen of $\mathrm{C} 57 \mathrm{BL} / 6$ mice. The vigorous secretion of IFN- $\gamma$ indicates that these cells are more likely to be mature NKT cells (51-53) and are likely to have been activated in vivo.

In the current study, we demonstrated that CD1dreactive tetramer-positive $\mathrm{CD}^{+} \mathrm{T}$ cells, accounting for about $5 \%$ of all $\mathrm{NZB} / \mathrm{W}$ splenic $\mathrm{CD}^{+} \mathrm{T}$ cells, are required for the in vitro augmentation of IgM and IgM anti-dsDNA Ab secretion by splenic $\mathrm{CD} 4^{+} \mathrm{T}$ cells. One hypothesis that explains the experimental results is that $C D 1 d^{\text {high }}$ autoreactive $B$ cells accumulate in the NZB/W spleen marginal zone and are stimulated to secrete IgM and then IgG autoantibodies by CD1dreactive $\mathrm{CD} 4^{+} \mathrm{NKT}$ cells in adult mice. NKT cells may not be pathogenic in NZB/W mice, however, in the first few weeks of life, since $\alpha$ GalCer treatment of 4-weekold NZB/W mice did not significantly augment the development of lupus disease parameters. CD1 $\mathrm{d}^{-/-}$ $\mathrm{NZB} / \mathrm{W}$ mice that are deficient in NKT cells have been reported recently to have more severe lupus as compared with $\mathrm{CD} 1^{+/+} \mathrm{NZB} / \mathrm{W}$ mice (64). This raises the possibility that there is an ameliorating role for NKT cells in early stages of immune maturation and that NKT cells contribute to and modulate development of disease activity as the mice age.

\section{Acknowledgments}

We thank Aditi Mukhopadhyay for technical assistance and Mary Hansen for her assistance in preparation of the manuscript. We are grateful to Yasuhiko Koezuka at the Kirin Pharmaceutical Research Institute for providing us with $\alpha \mathrm{GalCer}$. This research was supported by an Arthritis Foundation Investigator Award (to D. Zeng), NIH grant CA-52511 (to M. Kronenberg), and NIH grant AI-40093 (to S. Strober).

1. Kotzin, B.L. 1996. Systemic lupus erythematosus. Cell. 85:303-306.

2. Theofilopoulos, A.N., Kofler, R., Singer, P.A., and Dixon, F.J. 1989. Molecular genetics of murine lupus models. Adv. Immunol. 46:61-109.

3. Hahn, B.H. 1998. Antibodies to DNA. N. Engl. J. Med. 338:1359-1368. 4. O'Keefe, T.L., Datta, S.K., and Imanishi-Kari, T. 1992. Cationic residues in pathogenic anti-DNA autoantibodies arise by mutations of a germ- line gene that belongs to a large VH gene subfamily. Eur. J. Immunol. 22:619-624.

5. Via, C.S., and Shearer, G.M. 1988. T-cell interactions in autoimmunity: insights from a murine model of graft-versus-host disease. Immunol. Today. 9:207-213.

6. Satoh, M., and Reeves, W.H. 1994. Induction of lupus-associated autoantibodies in BALB/c mice by intraperitoneal injection of pristane. J. Exp. Med. 180:2341-2346.

7. Mendlovic, S., et al. 1988. Induction of a systemic lupus erythematosuslike disease in mice by a common human anti-DNA idiotype. Proc. Natl. Acad. Sci. U. S. A. 85:2260-2264.

8. Zeng, D., et al. 1998. Subsets of transgenic T cells that recognize CD1 induce or prevent murine lupus: role of cytokines. J. Exp. Med. 187:525-536

9. Ando, D.G., Sercarz, E.E., and Hahn, B.H. 1987. Mechanisms of T and B cell collaboration in the in vitro production of anti-DNA antibodies in the NZB/NZW F1 murine SLE model. J. Immunol. 138:3185-3190.

10. Borchers, A., Ansari, A.A., Hsu, T., Kono, D.H., and Gershwin, M.E. 2000. The pathogenesis of autoimmunity in New Zealand mice. Semin. Arthritis Rheum. 29:385-399.

11. Sobel, E.S., et al. 1991. An intrinsic B cell defect is required for the production of autoantibodies in the lpr model of murine systemic autoimmunity. J. Exp. Med. 173:1441-1449.

12. Roths, J.B., Murphy, E.D., and Eicher, E.M. 1984. A new mutation, gld, that produces lymphoproliferation and autoimmunity in $\mathrm{C} 3 \mathrm{H} / \mathrm{HeJ}$ mice. J. Exp. Med. 159:1-20.

13. Wofsy, D., Kerger, C.E., and Seaman, W.E. 1984. Monocytosis in the BXSB model for systemic lupus erythematosus. J. Exp. Med. 159:629-634.

14. Tsao, B.P., et al. 1990. Structural characteristics of the variable regions of immunoglobulin genes encoding a pathogenic autoantibody in murine lupus. J. Clin. Invest. 85:530-540.

15. Theofilopoulos, A.N. 1992. Murine models of systemic lupus erythematosus. In Systemic lupus erythematosus. R.G. Lahita, editor. Churchill Livingstone. New York, New York, USA. 121 pp.

16. Wofsy, D., and Seaman, W.E. 1985. Successful treatment of autoimmunity in NZB/NZW F1 mice with monoclonal antibody to L3T4. J. Exp. Med. 161:378-391.

17. Mohan, C., Adams, S., Stanik, V., and Datta, S.K. 1993. Nucleosome: a major immunogen for pathogenic autoantibody-inducing $T$ cells of lupus. J. Exp. Med. 177:1367-1381.

18. Ebling, F.M., Tsao, B.P., Singh, R.R., Sercarz, E., and Hahn, B.H. 1993. A peptide derived from an autoantibody can stimulate T cells in the (NZB $\times$ NZW)F1 mouse model of systemic lupus erythematosus. Arthritis Rheum. 36:355-364.

19. Singh, R.R., et al. 1995. T cell determinants from autoantibodies to DNA can upregulate autoimmunity in murine systemic lupus erythematosus. J. Exp. Med. 181:2017-2027.

20. Zeng, D., Lee, M.K., Tung, J., Brendolan, A., and Strober, S. 2000. Cutting edge: a role for CD1 in the pathogenesis of lupus in NZB/NZW mice. J. Immunol. 164:5000-5004.

21. Jacob, C.O., van der Meide, P.H., and McDevitt, H.O. 1987. In vivo treatment of $(\mathrm{NZB} \times \mathrm{NZW}) \mathrm{F} 1$ lupus-like nephritis with monoclonal antibody to gamma interferon. J. Exp. Med. 166:798-803.

22. Engleman, E.G., et al. 1981. Treatment of NZB/NZW F1 hybrid mice with Mycobacterium bovis strain BCG or type II interferon preparations accelerates autoimmune disease. Arthritis Rheum. 24:1396-1402.

23. Datta, S.K., Patel, H., and Berry, D. 1987. Induction of a cationic shift in IgG anti-DNA autoantibodies. Role of T helper cells with classical and novel phenotypes in three murine models of lupus nephritis. J. Exp. Med. 165:1252-1268.

24. Snapper, C.M., and Paul, W.E. 1987. Interferon-gamma and B cell stimulatory factor-1 reciprocally regulate Ig isotype production. Science. 236:944-947.

25. Stevens, T.L., et al. 1988. Regulation of antibody isotype secretion by subsets of antigen-specific helper T cells. Nature. 334:255-258.

26. Mendiratta, S.K., et al. 1997. CD1d1 mutant mice are deficient in natural T cells that promptly produce IL-4. Immunity. 6:469-477.

27. Porcelli, S.A. 1995. The CD1 family: a third lineage of antigen-presenting molecules. Adv. Immunol. 59:1-98.

28. Bendelac, A., Rivera, M.N., Park, S.H., and Roark, J.H. 1997. Mouse CD1specific NK1 T cells: development, specificity, and function. Annu. Rev. Immunol. 15:535-562.

29. Kawano, T., et al. 1997. CD1d-restricted and TCR-mediated activation of Valpha 14 NKT cells by glycosylceramides. Science. 278:1626-1629.

30. Joyce, S., et al. 1998. Natural ligand of mouse CD1d1: cellular glycosylphosphatidylinositol. Science. 279:1541-1544.

31. Gumperz, J.E., et al. 2000. Murine CD1d-restricted T cell recognition of cellular lipids. Immunity. 12:211-221.

32. Burdin, N., Brossay, L., and Kronenberg, M. 1999. Immunization with alpha-galactosylceramide polarizes CD1-reactive NK T cells towards Th2 cytokine synthesis. Eur. J. Immunol. 29:2014-2025.

33. Singh, N., et al. 1999. Cutting edge: activation of NK T cells by CD1d and 
alpha-galactosylceramide directs conventional $\mathrm{T}$ cells to the acquisition of a Th2 phenotype. J. Immunol. 163:2373-2377.

34. Hong, S., et al. 2001. The natural killer T-cell ligand alpha-galactosylceramide prevents autoimmune diabetes in non-obese diabetic mice. Nat. Med. 7:1052-1056.

35. Sharif, S., et al. 2001. Activation of natural killer T cells by alpha-galactosylceramide treatment prevents the onset and recurrence of autoimmune type 1 diabetes. Nat. Med. 7:1057-1062.

36. Wang, B., Geng, Y.B., and Wang, C.R. 2001. CD1-restricted NK T cells protect nonobese diabetic mice from developing diabetes. J. Exp. Med. 194:313-320.

37.Jahng, A.W., et al. 2001. Activation of natural killer $\mathrm{T}$ cells potentiates or prevents experimental autoimmune encephalomyelitis. J. Exp. Med. 194:1789-1799.

38. Naumov, Y.N., et al. 2001. Activation of CD1d-restricted T cells protects NOD mice from developing diabetes by regulating dendritic cell subsets. Proc. Natl. Acad. Sci. U. S. A. 98:13838-13843.

39. Zeng, D., et al. 1999. Heterogeneity of NK1.1 $1^{+} \mathrm{T}$ cells in the bone marrow: divergence from the thymus. J. Immunol. 163:5338-5345.

40. Zeng, D., et al. 1999. Bone marrow NK1.1 ${ }^{-}$and NK1.1 ${ }^{+} \mathrm{T}$ cells reciprocally regulate acute graft versus host disease. J. Exp. Med. 189:1073-1081.

41.Zeng, D., et al. 2002. Unique patterns of surface receptors, cytokine secretion, and immune functions distinguish $\mathrm{T}$ cells in the bone marrow from those in the periphery: impact on allogeneic bone marrow transplantation. Blood. 99:1449-1457.

42. Matsuda, J.L., et al. 2000. Tracking the response of natural killer T cells to a glycolipid antigen using CD1d tetramers. J. Exp. Med. 192:741-754.

43. Brossay, L., et al. 1997. Mouse CD1 is mainly expressed on hemopoietic-derived cells. J. Immunol. 159:1216-1224.

44. Cui, J., et al. 1999. Inhibition of T helper cell type 2 cell differentiation and immunoglobulin $\mathrm{E}$ response by ligand-activated Valpha14 natural killer T cells. J. Exp. Med. 190:783-792.

45. Coffman, R.L., Lebman, D.A., and Rothman, P. 1993. Mechanism and regulation of immunoglobulin isotype switching. Adv. Immunol. 54:229-270.

46. Steward, M.W., and Hay, F.C. 1976. Changes in immunoglobulin class and subclass of anti-DNA antibodies with increasing age in N/ZBW F1 hybrid mice. Clin. Exp. Immunol. 26:363-370.

47. Reininger, L., et al. 1996. Intrinsic B cell defects in NZB and NZW mice contribute to systemic lupus erythematosus in $(\mathrm{NZB} \times \mathrm{NZW}) \mathrm{F} 1$ mice. J. Exp. Med. 184:853-861.

48. Samuelsson, A., Towers, T.L., and Ravetch, J.V. 2001. Anti-inflammato- ry activity of IVIG mediated through the inhibitory Fc receptor. Science. 291:484-486.

49. Clynes, R., et al. 1999. Modulation of immune complex-induced inflammation in vivo by the coordinate expression of activation and inhibitory Fc receptors. J. Exp. Med. 189:179-185.

50. Szalay, G., et al. 1999. Cutting edge: anti-CD1 monoclonal antibody treatment reverses the production patterns of TGF-beta 2 and Th1 cytokines and ameliorates listeriosis in mice. J. Immunol. 162:6955-6958.

51. Benlagha, K., Kyin, T., Beavis, A., Teyton, L., and Bendelac, A. 2002. A thymic precursor to the NK T cell lineage. Science. 296:553-555.

52. Pellicci, D.G., et al. 2002. A natural killer T (NKT) cell developmental pathway involving a thymus-dependent $\mathrm{NK} 1.1^{-} \mathrm{CD} 4^{+} \mathrm{CD} 1 \mathrm{~d}$-dependent precursor stage. J. Exp. Med. 195:835-844.

53. Gadue, P., and Stein, P.L. 2002. NK T cell precursors exhibit differential cytokine regulation and require Itk for efficient maturation. J. Immunol. 169:2397-2406.

54. Chen, H., Huang, H., and Paul, W.E. 1997. NK1.1 ${ }^{+} \mathrm{CD} 4{ }^{+}$T cells lose NK1.1 expression upon in vitro activation. J. Immunol. 158:5112-5119.

55. Amano, M., et al. 1998. CD1 expression defines subsets of follicular and marginal zone B cells in the spleen: beta 2-microglobulin-dependent and independent forms. J. Immunol. 161:1710-1717.

56. Roark, J.H., et al. 1998. CD1.1 expression by mouse antigen-presenting cells and marginal zone B cells. J. Immunol. 160:3121-3127.

57. Peng, S.L., Moslehi, J., and Craft, J. 1997. Roles of interferon-gamma and interleukin-4 in murine lupus. J. Clin. Invest. 99:1936-1946.

58. Santiago, M.L., et al. 1997. Interleukin-4 protects against a genetically linked lupus-like autoimmune syndrome. J. Exp. Med. 185:65-70.

59. Miyamoto, K., Miyake, S., and Yamamura, T. 2001. A synthetic glycolipid prevents autoimmune encephalomyelitis by inducing TH2 bias of natural killer T cells. Nature. 413:531-534.

60. Carnaud, C., et al. 1999. Cutting edge: cross-talk between cells of the innate immune system: NKT cells rapidly activate NK cells. J. Immunol. 163:4647-4650.

61. Amigorena, S., Bonnerot, C., Fridman, W.H., and Teillaud, J.L. 1990. Recombinant interleukin 2-activated natural killer cells regulate IgG2a production. Eur. J. Immunol. 20:1781-1787.

62. Wilder, J.A., Koh, C.Y., and Yuan, D. 1996. The role of NK cells during in vivo antigen-specific antibody responses. J. Immunol. 156:146-152.

63. Racke, F.K., Clare-Salzer, M., and Wilson, S.B. 2002. Control of myeloid dendritic cell differentiation and function by CD1d-restricted (NK) T cells. Front. Biosci. 7:d978-d985.

64. Hong, S., et al. 2001. Genetic deletion of CD1 in lupus: evidence of a regulatory role. Arthritis Rheum. 44(Suppl.):283. (Abstr.) 